\title{
BUMBA MEU BOI DO MARANHÃO E O DISCURSO RELIGIOSO: O BOI NÃO É SÓ FESTA, MEU POVO
}

\author{
BUMBA MEU BOI DO MARANHÃO AND THE RELIGIOUS \\ SPEECH: THE BOI IS NOT JUST A PARTY, MY PEOPLE
}

\author{
Marcelo Nicomedes dos Reis Silva Filho ${ }^{1}$ \\ [https://orcid.org/0000-0002-9715-2099] \\ Leila Silvana Pontes ${ }^{2}$ \\ [https://orcid.org/0000-0002-8596-1008] \\ DOI: 10.30612/raido.v15i37.14664
}

\begin{abstract}
RESUMO: Este estudo analisa a história do Bumba-boi, produçăo cultural que narra a relaçấo entre três etnias: a do índio, a do negro e a do branco, que compóem a miscigenaçăo dos sujeitos maranhenses. Esse entrelace marca uma narrativa de trabalho, exploraçáo e violência através da conversăo e do sufocamento das culturas consideradas menores, como a do negro e a do índio. Narrativa de tensâo, materializada na representaçấo do auto e o imbricamento material, na produçâo audiovisual e linguística, sâo os elementos com os quais nos ocuparemos nesta pesquisa. Tendo o discurso religioso como foco, nosso objetivo é responder às perguntas discursivas: como se materializa o discurso religioso na produçăo do Bumba meu boi do Maranhăo no sotaque de matraca? Que efeitos de sentido săo produzidos a partir da relaçăo Bumba meu boi/discurso religioso nas toadas do Bumba-boi que compóem o corpus da pesquisa? A análise apoiou-se em: Pêcheux (1999; 2014), Orlandi (1987 2015), Indursky (2011). A pesquisa mostrou que efeitos de sentido do corpus năo se esgotam e que, mesmo com o funcionamento do lúdico na festa do Bumba meu boi, permanece o discurso religioso, responsável pela retomada de alguns dizeres dos tempos coloniais e da Idade Média.
\end{abstract}

Palavras-chave: Bumba meu boi, Discurso Religioso, Formaçăo Discursiva, Memória.

ABSTRACT: This study analyzes the history of Bumba-boi, a cultural production that narrates the relationship between three ethnic groups: the Indian, the black and the white, which make up the miscegenation of individuals from Maranhâo. This interweaving marks a narrative of work, exploitation and violence through the conversion and suffocation of cultures considered minor, such as the black and the

1 Bolsista FAPEMA, Doutor em Letras pelo PPGL Unioeste, Mestre em Educaçăo pelo PPGE UCB, Professor do Curso de Licenciatura em Linguagens e Códigos - UFMA Campus Săo Bernardo. marcelo.nicomedes@ ufma.br.

2 Doutoranda em Letras pelo PPGL Unioeste, Mestre em Letras pela UEM, Professora do IFPR - Campus Umuarama. leila.pontes@ifpr.edu.br. 
Indian. Tension narrative, materialized in the representation of the self and the material overlapping, in the audiovisual and linguistic production, are the elements that we will deal with in this research. Having the religious discourse as the focus, our objective is to answer the discursive questions: how is the religious discourse materialized in the production of Bumba meu boi do Maranhâo in a rattlesnake accent? What meaning effects are produced from the relationship Bumba meu boi/religious discourse in the tunes of Bumba-boi that make up the corpus of the research? The analysis was based on: Pêcheux (1999; 2014), Orlandi (1987 2015), Indursky (2011). The research showed that the corpus's meaning effects are not exhausted and that, even with the playful functioning of the Bumba meu boi festival, the religious discourse remains, responsible for the resumption of some sayings from colonial times and the Middle Ages.

Keywords: Bumba meu boi, Religious Discourse, Discursive Formation, Memory

\section{INTRODUÇÃO}

A produçâo cultural no Maranhăo é marcada por uma diversidade de folguedos, ou seja, por festas populares com danças e músicas, que narram a relaçăo existente entre três etnias: a do índio, a do negro e a do branco, que compóem a miscigenaçăo dos sujeitos maranhenses. A história do Bumba-boi apresenta, em forma de auto ${ }^{3}$ resumido, a história colonial da constituiçâo de uma vida rural, que remonta aos tempos coloniais e ciclo do gado no Nordeste brasileiro. Desta forma, Fazendeiro, Amo, Vaqueiros, Índias, Caboclos de Pena (Real), Caboclos de Fita, burrinha e o boi em si, compóem o elenco do maior folguedo do Estado do Maranhâo.

Como manifestaçăo cultural, essas etnias se entrelaçam em meio a uma narrativa que apresenta relaçăo tanto de trabalho e de exploraçâo quanto de formas de violência por meio da conversâo e do sufocamento das culturas consideradas menores, como a do negro e a do índio, nesse contexto. Essa relaçấo de tensâo se materializa nas formas de representaçâo do auto; o imbricamento material, na produçăo audiovisual e linguística, sâo os elementos com os quais nos ocuparemos nesta pesquisa.

Por meio das toadas do Boi, das indumentárias ou até mesmo das performances dos corpos das personagens nas apresentaçôes, podemos notar os mais diversos funcionamentos dos discursos, os quais, focalizaremos, aqui, no atravessamento religioso no Bumba meu boi. Tendo o discurso religioso como foco principal da nossa pesquisa, partimos das perguntas que se ensejam: como se materializa o discurso religioso na produçấo do Bumba meu boi do Maranhăo no sotaque de matraca? Que efeitos de sentido săo produzidos a partir da relaçấo Bumba meu boi/discurso religioso nas toadas do Bumba-boi que compóem o corpus da pesquisa?

A partir dessas perguntas, nosso objetivo é analisar como se apresenta o discurso religioso nas toadas e outras em materialidades da produçấo do Bumba meu boi no sotaque de Matraca. Para isso, trabalharemos, principalmente, com a tipologia do discurso apresentado por Orlandi (1987), os postulados sobre memória de Pêcheux (1999), Indursky (2011, 2013), dentre outros autores da análise de discurso de linha materialista.

3 Segundo Massaud Moisés (1985, p. 49), "auto designa toda peça breve, de tema religioso ou profano, em circulaçăo durante a Idade Média: equivaleria a um ato que integrasse espetáculo maior e completo; daí o apelativo que recebeu: auto". 
Na próxima seçăo, apresentaremos os postulados que sustentam nossas proposiçóes juntamente com o corpus de pesquisa. Dessa forma, teremos como discutir as noçóes sobre o discurso elencadas para as análises de maneira que possamos trabalhar no entremeio das materialidades, mais precisamente, no equívoco constitutivo da língua e no trabalho da história sobre os objetos simbólicos, que trazemos para o campo do discurso nesta análise.

\section{TEORIA DO DISCURSO: ALGUMAS NOÇÕES E TIPOLOGIA DO DISCURSO.}

A formaçăo discursiva (doravante FD), na perspectiva de Pêcheux, mostra-se em uma relaçâo intrínseca com a ideologia (INDURSKY, 2016), que fornece aos sujeitos as evidências necessárias para que palavras e enunciados lhes sejam reconhecidos, ou seja, através da ideologia, sabe-se o que "é um soldado, um operário, um patrâo, uma fábrica, uma greve etc..." (PECHEUX, 2014, p. 146). Isso cria no sujeito, segundo o autor, a falsa impressâo de que a linguagem é transparente, de que o sentido é colado às palavras, às expressóes, às proposiçōes, quando, na verdade, seu sentido é determinado por posiçōes ideológicas nas quais sāo produzidas (ou reproduzidas), considerando aspectos sociais e históricos. Em outros termos, o sentido năo está na palavra, mas é atribuído a ela de acordo com a posiçáo que o sujeito que a emprega ocupa, "elas adquirem seu sentido em referência a essas posiçōes" (PECHEUX, 2014, p. 147), ou seja, "palavras, expressóes, proposiçōes etc., recebem seu sentido da formaçăo discursiva na qual săo produzidas". (PECHEUX, 2014, p. 146 - grifo nosso).

Partindo desse postulado de Pêcheux (2014), apresentamos a SD1, nela trazemos a primeira toada, que é do Bumba boi da Maioba, interpretada pelo cantador Chagas. Algumas palavras demonstram as posiçōes de classe ou ideológicas daquele que enuncia. Observemos a seguir:
SD1: No bumba meu boi tem segredo e tem magia
Tem a promessa do santo e a proteçáo do guia
Formei trincheira com fama de vencedor
Quem năo sabe bate palma pra quem é merecedor
Graças a Deus minha estrela está brilhando
Sei que sou apreciado por quem me ouve cantando.
(Chagas - Bumba-meu-boi da Maioba, Maioba e Lencois! Amor à primeira vista, faixa 8, 2015, negritos nossos).

Partimos das palavras segredo e magia, elas remetem a dizeres que săo retomados nas celebraçóes das religióes católica e de matriz africana. O segredo ${ }^{4}$, aqui retoma-

4 Segundo Montfor (2018), com base na perspectiva da religiăo católica, o segredo consiste no fato de que, assim como Deus usou Maria como meio para se aproximar dos homens através de seu filho, assim os homens têm de ser humildes como Cristo foi e reconhecerem Maria como um caminho para Deus. Conhecida como "Mater Gratiae" (MONTFOR, 2018, p. 4), Maria alcançou graça diante de Deus que nenhum outro personagem bíblico foi capaz de conquistar e, de acordo com as premissas do autor, é considerada o caminho mais rápido, mais curto e menos doloroso para a salvaçâo. Sua mensagem envolve convite à consagraçấo, ao arrependimento, à conversăo. 
do, faz referência aos segredos de Maria, măe de Jesus Cristo, aqueles que creem nos mistérios de Maria, repetem, em oraçáo, às apariçóes de Nossa Senhora. Na toada, o segredo reverbera outros sentidos, năo mais os segredos de Maria conforme os efeitos de sentido atribuídos pela igreja católica, mas aos ritos de religióes de Matriz africana, já que as marcas ideológicas na qual a palavra foi materializada, a posiçâo do sujeito, ou seja, a FD sâo outras (PÊCHEUX, 2014).

Assim, para o cantador, o segredo se refere às oferendas, aos rituais, que săo trabalhados por meio do sincretismo religioso, e, năo ficando fora dessa relaçăo religiosa, o culto direto aos Voduns e aos Orixás. Magia, a outra palavra que trazemos para a discussăo, intensifica os sentidos de segredo. Para muitas pessoas, as religiōes de matriz africana e pajelança sâo vistas de forma preconceituosa devido aos dizeres que foram sendo repetidos com o intuito de demonizar as religióes e os cultos trazidos pelos escravos quando traficados da África para as américas.

A conversăo e a expropriaçấo das memórias dessas comunidades, aos poucos, foram sendo silenciadas; favorecendo, com isso, a conversăo daqueles sujeitos, chamados como peças, considerados verdadeiros objetos vivos. A dominaçăo, tanto de negros como de índios, seria facilitada, se năo houvesse um fortalecimento das crenças, que aqueles povos demonstravam, quando as américas foram colonizadas.

O Bumba-boi reúne memórias das três etnias que constituem a populaçáo de habitantes do estado do Maranhâo. Desde que surgiu no Estado como folguedo, está no meio de uma disputa de forças, pois năo era aceito pela igreja católica, era tido como bagunça promovida por escravos e como algo que fomentava a balbúrdia (CASCUDO, 2006).

Contudo, em "tem a promessa do santo e a proteçâo do guia", observamos como, ao passar dos anos, a relaçăo de aproximaçáo entre as religiôes foi mudando, mas isso năo quer dizer que os sujeitos que produzem, nos dias de hoje, o Bumba meu boi foge a essa tensăo que é constitutiva do folguedo. Os cantadores, como sujeitos, assumem posiçóes de classe, em parte motivada por atravessamentos religiosos. A promessa ao santo e a proteçâo do guia demonstram esse funcionamento discursivo do discurso religioso. Sáo as vozes de Deus (ORLANDI, 1987) apresentando dois entendimentos da enunciaçáo da voz de Deus no discurso do Boi. O entendimento mais aprofundado sobre FD vai nos ajudar no entendimento do que estamos propondo.

Como observamos acima, as palavras săo vazias de sentido. Elas ganham seu sentido, ou efeito de sentido, quando os sujeitos enunciam a partir das suas posiçóes ideológicas e isso ocorre quando esse sujeito é afetado pela ideologia da formaçăo discursiva que o domina.

Além de ser o lugar de atribuiçâo de sentido, a "formaçăo discursiva dissimula, pela transparência do sentido que nela se constitui, sua dependência com respeito ao 'todo complexo com dominante' das formaçôes discursivas" (PECHEUX, 2014, p. 148-149), 'todo complexo' a que o autor denomina de interdiscurso. E é, nessa relaçâo interdiscursiva, que a FD define seus limites e articula "formulaçôes aceitáveis (isto é, ela determina 'o que pode e deve ser dito') e excluindo formulaçōes inaceitáveis a esse domínio (isto, é, determina 'o que nâo pode/nâo deve ser dito')" (BRANDĀo: 1998, p. 126).

Quando retomamos os versos 3, 4, 5 e 6 da SD1, notamos que existe um funcionamento ideológico que aponta para o discurso religioso, pois, ao falar que "graças a Deus" a sua estrela está brilhando, o sujeito exclui os outros sujeitos que năo acreditam 
em Deus, aqui se materializa o Deus católico da bíblia. Esse pensamento corrobora com as palavras de Indursky (2011). Mas a autora salienta que é necessário pontuar que, mesmo que a FD determine o que é aceitável ou năo dentro de seus limites, ela nâo é fechada, os sentidos

podem atravessar as fronteiras da FD onde se encontram, e deslizarem para outra FD, inscrevendo-se, por conseguinte, em outra matriz de sentido. Ao migrarem, esses sentidos passam a ser determinados por outras relaçóes com a ideologia. Essa movimentaçâo nas filiaçóes dos sentidos só é possível porque, ao migrarem, esses sentidos se ressignificam. Percebe-se, pois, que o fechamento das FDs năo é rígido e suas fronteiras săo porosas, permitindo migraçáo (INDURSKY, 2011, p. 71).

A FD, por năo possuir fronteiras rígidas, estabelece relaçăo interdiscursiva. 0 sujeito, ao articular seu discurso, inevitavelmente instaura outro, um năo-dito, por exemplo (INDURSKY, 2000), acionando outros dizeres, pois "há sempre no dizer um năo-dizer necessário. Quando se diz ' $x$ ', o nâo-dito 'y' permanece como uma relaçăo de sentido que informa o dizer de 'x' (ORLANDI: 2015, p.81), ou seja, uma FD pressupóe uma outra. Retomemos os versos mencionados acima $(3,4,5$ e 6$)$ :

\section{SD1: Formei trincheira com fama de vencedor \\ Quem năo sabe bate palma pra quem é merecedor \\ Graças a Deus minha estrela está brilhando \\ Sei que sou apreciado por quem me ouve cantando.}

Tendo em vista que a língua năo é transparente e náo é fechada em si mesma, outros sentidos podem ser formulados ainda na FD religiosa católica. No verso "graças a Deus minha estrela está brilhando", notamos os sentidos do cristianismo funcionando por meio da paráfrase, buscando estabilizar os sentidos de que o Deus mencionado pela toada é o do cristianismo. E estrela que brilha produz o efeito da estrela que guiou os reis magos, como no relato bíblico ao Messias. Ou seja, a fé no Deus todo poderoso da bíblia se intensifica por meio do sacrifício de Cristo que, no relato bíblico, comprou os pecados com seu sangue, desta forma, Jesus Cristo é a estrela que brilha e guia aqueles que acreditam no sacrifício para a salvaçâo.

Há que se destacar que, além do que 'pode e deve ser dito dentro da FD', há interlocuçâo: relaçâo entre os sujeitos do discurso. Diferentemente da teoria da enunciaçấo, que aponta a supremacia do locutor "eu" sobre o ouvinte, numa relaçăo que se alterna em turnos sucessivos e que considera a linguagem como interaçăo, comunicaçăo e informaçăo, supondo transparência (relaçăo direta entre pensamento e linguagem), há conflitos. Quanto a isso, Orlandi (1987, p. 151) se posiciona da seguinte maneira:

Do meu ponto de vista năo é tudo placidez: há tensăo, confronto, reconhecimento e mesmo conflito na tomada de palavra. Há tensăo entre texto e contexto (social, histórico-social). Há tensăo entre interlocutores: tomar a palavra é um ato social com todas as suas implicaçóes. E se há sentido em se falar em dois 'eus' é no sentido de que há conflito na constituiçăo dos sujeitos.

No verso 5 da SD1, "graças a Deus minha estrela está brilhando", o enunciado em primeira pessoa denuncia o sujeito e demonstra que os sentidos deslizam por conta 
da exposiçâo do enunciado ao simbólico; exposto à contradiçăo da história e à falha da língua, os sentidos se produzem, sempre levando em consideraçăo as condiçóes de produçăo.

A autora levanta implicaturas históricas e sociais na interaçăo e, segundo ela, nâo há homogeneidade nem simetria nem estabilidade entre os interlocutores e as diferenças năo săo apenas culturais, elas "se originam no fato de haver vários tipos de discurso. A isso eu chamaria variaçâo inerente" (ORLANDI, 1987, p.151). Por isso, defende a necessidade metodológica de estabelecer critérios para analisar o discurso, como a noçăo de 'tipo'. Assim, de acordo com seu ponto de vista, é possível relacionar FD à tipologia, uma vez que esta tem conceito

Mediador no sentido de que é configurado por certas marcas, certos traços formais ao mesmo tempo em que é definido por sua relaçâo com a formaçăo ideológica. Quer dizer, é através da caracterizaçâo dos funcionamentos discursivos que podemos determinar as formaçôes discursivas que, por sua vez, sâo definidas pela sua relaçáo com a formaçấo ideológica (ORLANDI, 1987, p. 232)

Em outras palavras, em uma FI determinada, a FD, "a partir de uma posiçâo dada numa conjuntura dada, determinada pelo estado de luta de classes, determina o que pode e deve ser dito" (PÊCHEUX, 2014, p. 147).

\section{SOBRE A TIPOLOGIA DO DISCURSO}

A forma como o discurso religioso se apresenta nos diz bastante sobre seu funcionamento. Nesse aspecto, trazer para a discussáo as tipologias discursivas contribui para o entendimento de que formas de discurso se apresentam em nosso corpus e como elas podem estar imbricadas no funcionamento deste discurso religioso.

A analista, ao falar de tipos, nâo os considera em parâmetros tradicionais didáticos como dissertativo, descritivo e narrativo; nem em critérios institucionais (ou de conhecimento) como religioso, jurídico e científico, pois acredita que a "um tipo de discurso resulta do funcionamento discursivo, sendo este último definido como atividade estruturante de um discurso determinado, para um interlocutor determinado, por um falante determinado, com finalidades específicas" (ORLANDI, 1987, p. 153). Importa ressaltar que o termo 'determinado' năo se refere a uma pessoa física, mas sim a projeçōes imaginárias que o sujeito faz de seu interlocutor levando em consideraçăo as posiçóes que ocupam, afetadas pelos aspectos sociais e ideológicos.

Para Orlandi (ORLANDI, 1987, p. 152, itálicos da autora), a tipologia

Devia dar conta da relaçáo linguagem/contexto, compreendendo-se contexto em seu sentido estrito (situaçáo de interlocuçăo, circunstância de comunicaçáo, instanciaçăo de linguagem) e no sentido lato (determinaçôes histórico-sociais, ideológicas, etc.)

Em suma, essa tipologia devia incorporar a relaçăo da linguagem com suas condiçôes de produção.

À sua compreensấo de tipologia, a autora associa critérios de interaçăo e de polissemia. O primeiro critério tem a ver com o modo como os interlocutores se consideram 
- nesse caso inscreve-se, ainda, o critério de reversibilidade, que consiste na troca de papeis entre os interlocutores dependendo da dinâmica da interaçâo; o segundo critério, a polissemia, diz respeito ao objeto do discurso, ao modo como os interlocutores se relacionam com ele: se os interlocutores apenas se expóem ao objeto de discurso; ou se o objeto de discurso está dominado apenas pelo falante; ou se está em disputa entre os interlocutores. A intensidade da carga polissêmica será maior ou menor dependendo dessa relaçăo. Disso, resulta os tipos de discurso propostos por Orlandi (1987, p.154-155):

Discurso lúdico: é aquele em que a reversibilidade entre interlocutores é total, sendo que o objeto do discurso se mantém como tal na interlocuçáo, resultando disso a polissemia aberta. 0 exagero é o non sense.

Discurso polêmico: é aquele em que a reversibilidade se dá

sob certas condiçóes e em que o objeto do discurso está presente, mas sob perspectivas particularizantes dadas pelos participantes que procuram lhe dar uma direçăo, sendo que a polissemia é controlada. O exagero é a injúria.

Discurso autoritário: é aquele em que a reversibilidade tende a zero, estando o objeto do discurso oculto pelo dizer, havendo um agente exclusivo do discurso e a polissemia contida. $O$ exagero é a ordem no sentido militar, isto é, o assujeitamento ao comando.

A autora acrescenta que para o discurso lúdico, a funçâo referencial nâo importa, ele difere significativamente dos demais por usar a linguagem como prazer e năo para fins práticos ou imediatistas. Nesse caso, ela o considera uma "ruptura" visto que, de acordo com seu ponto de vista, năo há lugar para ele em nossa estrutura social. $O$ discurso polêmico respeita a funçáo referencial e os interlocutores disputam a verdade; por outro lado, no discurso autoritário, náo há disputa, a referência é exclusividade de um locutor. Apesar da divisăo aqui exposta, "os tipos de discurso nâo têm de existir necessariamente de forma pura. Há mistura de tipos e, além disso, há um jogo de dominância entre eles que deve ser observado em cada prática discursiva" (ORLANDI, 1987, p. 155-156). Em linhas gerais, a autora define 'tipo' como produto discursivo, formas cristalizadas de "funcionamentos (processos) definidos na própria relaçăo de interlocuçăo" (ORLANDI, p. 231) e seu conceito de tipologia "considera como constitutiva a relaçăo com as condiçôes de produçăo, com a formaçăo ideológica" (ORLANDI, p. 230), pois, é a partir dessa relaçăo, que a tipologia dever ser interpretada:

cuidado em relaçăo à interpretaçăo dessa (ou qualquer outra) tipologia. A sua interpretaçâo deve levar em conta as condiçôes de produçáo dos textos analisados e a relaçáo com a formaçáo ideológica. Isto quer dizer que, na interpretaçáo das características do texto que o situam em uma formaçấo discursiva e năo outra, năo podemos prescindir do contexto sócio-histórico (ORLANDI, 1987, p. 233)

O discurso religioso constitui-se como autoritário, ele tende à monossemia: "Os sentidos náo podem ser quaisquer sentidos: o discurso religioso tende fortemente para a monossemia. No cristianismo, enquanto religiăo institucional, a interpretaçăo própria é a da Igreja" (ORLANDI, 1987, p. 246). Esse discurso, de acordo com a 
autora, procura, sem sucesso, estancar a polissemia, visto que os sentidos náo podem ser controlados pelo locutor.

A reversibilidade, que, segundo Orlandi, é condiçăo para todo o discurso, nâo se manifesta, de fato, no discurso religioso, nele, encontra-se a "ilusâo de reversibilidade", pois se a reversibilidade é zero, "o discurso se rompe, desfaz-se a relaçăo, o contato, e o domínio (o escopo) do discurso fica comprometido. Daí a necessidade de se manter o desejo de torná-lo reversível. Daí a ilusăo" (ORLANDI, 1987, p. 140). Nele, a voz do padre e do pastor, por exemplo, sâo consideradas a voz do próprio Deus, nesse sentido, institui-se um desnivelamento entre a posiçăo do locutor (que se encontra em um plano elevado, espiritual, representando Deus) e a posiçáo do público (que se encontra em um plano terreno, o homem). De um lado, tem-se o locutor (Deus/eterno); de outro, o público (homem/efêmero): "Na desigualdade, Deus domina os homens" (ORLANDI, 1987, p. 243). Conforme a autora, essa dessimetria aponta para a năo-reversibilidade, uma vez que o homem năo pode ocupar o lugar do locutor, o lugar de Deus.

Segundo Orlandi, há formas cristalizadas e ritualizadas para que o homem se dirija a Deus, e, mesmo quando isso acontece, năo há reversibilidade, pois, os interlocutores năo alternam suas posiçóes: de um lado, permanece o divino; de outro, o humano. Assim:

a dissimetria se mantém é preciso que os homens, para serem ouvidos por Deus, se submetam às regras: eles devem ser bons, puros, devem ter mérito, ter fé, etc. É preciso, pois, que eles assumam a relaçâo da dualidade, a relaçấo com o Sujeito diante do qual a alma religiosa se define: esses sujeitos, para serem ouvidos, assumem as qualidades do espírito, qualidades do homem que tem fé (ORLANDI, 1987, p. 247).

Mesmo a fé, que articula o homem a Deus e que consiste na crença de que o pecado existe, sendo ela a possibilidade de direcionar o homem para a salvaçáo, "nâo é capaz de modificar a relaçấo de năo-reversibilidade do discurso religioso: a fé é uma graça recebida de Deus pelo homem" (ORLANDI, 1987, p. 251). Ela mesma vem de cima para baixo - uma açăo divina.

Orlandi (1987, p. 252) aponta como fator principal para a nâo-reversibilidade do discurso religioso sua principal diferença em relaçăo a outros discursos, o fato de que "ser representante, no discurso religioso, é estar no lugar de, năo é estar no lugar próprio". Assim, os lugares dos interlocutores nâo sâo disputados, pois a pessoa que fala, o interlocutor, representa Deus, fala do lugar dele, năo é Deus e, portanto, nâo disputa um lugar que năo é seu. Por outro lado, nâo caberia ao ouvinte disputar um lugar com o divino.

Ainda conforme a autora, o envolvimento do homem com o sagrado se dá pelo desejo de completude, de ultrapassar o limite, o visível; se dá pelo desejo de ter poder absoluto. Esse desejo pode configurar em uma identificaçăo com Deus ou em "transgressāo. Esta também é uma forma de experimentar o lugar do poder absoluto. E é nessa relaçáo com o poder que reside o prazer de transgredir" (ORLANDI, 1987, p. 254). No discurso religioso, no que se refere ao Cristianismo, o homem năo possui escolha, esse discurso possui a sua verdade: ou ele se identifica com Deus ou pratica o mal (transgride). 


\section{OS EFEITOS DE SENTIDO DO DISCURSO RELIOSO NO BUMBA MEU BOI}

A segunda sequência discursiva que iremos analisar é do mesmo grupo de Bumba meu boi (Boi da Maioba), embora náo sejam sequência uma da outra, apresentam uma regularidade que se enseja como um achado, o qual demonstra o funcionamento da memória operado pelo jogo de forças que busca inscrever novas séries sobre outras já existentes (PECHEUX, 1999). Esse movimento característico da memória operada por meio de uma série de repetiçôes, de retomadas, de deslizamentos e de deslocamentos, que sâo possíveis pelo efeito metafórico. Veremos, no decorrer da análise, como isso ocorre na SD2. Apresentamos a sequência discursiva abaixo:

SD2: Touro da Maioba urrou levantou quebrando tudo

Ele é o dono da multidāo

Deu um tombo na tenda do cantor que é curador

Segredo virou bagunça espalhado pelo chăo

Depois correu atoado se jogou na maré

Banzeiro te enganou na passagem do garapé

Eu arrasei foi com Iguaíba

O medalhăo caiu me pedindo perdāo

No asilo do Oiteiro

foi grande a confusăo

O urro que meu boi deu acabou com um boi grandalhấo.

(Chagas - Bumba-meu-boi da Maioba, Estrela brasileira, faixa 8, 2013, negritos nossos).

Retomando o objetivo que nos moveu até aqui, neste percurso analítico, em que buscamos analisar como se apresenta o discurso religioso nas toadas e outras materialidades da produçâo do Bumba meu boi no sotaque ${ }^{5}$ de Matraca, passaremos para o segundo movimento analítico. A partir daqui, apresentamos os efeitos de sentido produzidos nas duas toadas, contudo, focalizaremos a segunda. Na primeira toada, detemo-nos em demonstrar o funcionamento das categorias de análises que trouxemos para o batimento teoria/corpus.

A toada que apresentamos agora, dentro da organizaçáo do auto do Bumba meu boi, é descrita como o Urro do Boi. Nesta seçăo da apresentaçăo do folguedo, săo cantadas toadas que nos demonstram como o Boi volta à vida; é o momento do Boi colocar, no terreiro, toda sua vitalidade e alegrar o fazendeiro e todos os empregados da fazenda com o seu retorno.

O Boi passa a desempenhar um papel importante no auto, é ele o objeto simbolizado; é o ser ressuscitado, que demonstrará todo o seu poder, como observamos em "Touro da Maioba urrou levantou quebrando tudo/ Ele é o dono da multidăo". O Boi da Maioba aqui referenciado é um dos mais populares e conhecidos Boi do sotaque

$5 \quad$ O sotaque segundo Azevedo Neto (2019), é o estilo em que o Bumba meu boi se apresenta. Esse estilo leva em consideraçăo a indumentária dos grupos, a forma como os bois se apresenta, ritmo, etc. No Bumba meu boi do Maranhâo apresente cinco sotaques principais, sâo eles: Zabumba (Guimarâes), Costa de Máo (Cururupu), Baixada (Pindaré), Orquestra e Matraca (Ilha). 
de Matraca do Maranháo. Considerado o mais querido pela sua popularidade, tem a fama de arrastar multidóes por onde passa, e isso reverbera nos versos iniciais da toada, presente na SD2. Os sentidos de religiosidade fazem funcionar memórias de narrativas bíblicas. No relato bíblico, a expressăo "levanta e anda", apresenta equivalência de sentido com "touro da Maioba urrou levantou quebrando tudo"; por funcionamento do efeito metafórico, o levantar quebrando tudo produz o efeito do inacreditável, do sentido do milagre, năo só de retornar a vida, mas a volta com todas as suas forças vitais restabelecidas. Temos aí a intensificaçâo dos sentidos de cura.

Como entendemos, seguindo Orlandi (1987), o discurso religioso é aquele em que fala a voz de Deus. É essa retomada do dizer do filho de Deus que é repetida pelo discurso que atravessa o Bumba meu boi em forma de paráfrase, que demonstra o funcionamento náo somente do discurso religioso cristăo, mas alguns efeitos do estabelecimento deste discurso religioso que se instalou no Brasil desde o período colonial. Como mencionamos na seçăo anterior desse trabalho, as posiçóes assumidas pelos sujeitos săo ideológicas, ou seja, de classe. Mas como isso se reflete no Bumba meu boi do Maranháo no sotaque de Matraca? Partindo de nosso corpus de pesquisa, avançando na análise da SD2, o jogo de forças que é responsável por regular e desregular sentidos no interior das formaçóes discursivas, é o mesmo que faz com que entendamos que o que move a história é a luta de classes.

É pelo real da história que notamos que a contradiçáo se faz presente nos discursos. Outro ponto fundamental é a falha da língua, sua impossibilidade de dizer tudo ao mesmo tempo e de náo produzir o mesmo efeito em sujeitos diversos. É por meio dessa reaçâo de contradiçâo e de falha que avançamos em nossa análise. Na SD1, toada do mesmo autor, notamos que existe uma referência à relaçăo de equivalência dos rituais, pelo menos em parte. Há a afirmaçăo de que dentro dos dogmas presentes nas duas religióes, a católica e a de matriz africana, a palavra segredo, em nossas condiçóes de produçáo do Bumba meu boi, passa por um estado de deriva que năo permite uma estabilizaçáo de sentido. O segredo é deslocado para o campo do sobrenatural, năo importa se é o segredo de Maria ou do Caboclo ou Orixá, existe uma memória do discurso religioso que movimenta os dizeres em torno desta palavra.

Apontamos segredo e magia como vocábulos que movimentam sentidos que nâo estăo na ordem da estabilizaçâo dos sentidos, pelo contrário, eles se estabelecem como ponto de deriva dos sentidos do discurso religioso, mas que discurso é esse? É um discurso de uma formaçáo discursiva religiosa católica ou de religiăo de matriz africana?

Na toada seguinte, na SD2, a partir dos versos 3 e 4, notamos que a memória colonial e da Idade Média faz movimentar sentidos. Há uma retomada da condenaçáo das práticas de culto a entidades de religiōes de Matriz africana e Pajelança.

Essa demonizaçăo é notada na SD2 nos versos 3 e 4 como vemos em "Deu um tombo na tenda do cantor que é curador/ Segredo virou bagunça espalhado pelo chăo", no trecho percebemos a repetiçăo do discurso de repressăo às religiōes de Matriz africana e Pajelança. O Boi retorna à vida como agente do discurso autoritário do colonizador. O funcionamento do discurso autoritário por meio das toadas com uma roupagem de discurso lúdico silencia outros funcionamentos. É pelo lúdico que a conversăo do outro se processa, retomando memórias de opressăo e silenciamento secular das culturas do negro e do índio. A conversáo que ocorria para desbestializar 
o negro e, no caso do índio, amansá-lo, é apresentada como puro efeito do natural. As batalhas sangrentas contra os mouros, nas costas africanas, săo outro exemplo do discurso da expansáo marítima com uma causa religiosa.

O objetivo năo era conquistar a terra, poderíamos pensar, mas a conversăo daquele povo que era pagâo e que deveria aceitar a religiâo católica cristă como forma de alcançar a salvaçấo no reino dos céus, mesmo que isso ocorresse às custas de muitas vidas de ambos os lados.

Quando temos "deu um tombo na tenda do cantor que é curador", os sentidos da religiăo do colonizador, aquela que invade, destrói e conquista săo reverberados no enunciado. $O$ outro cantador, que tem sua toada respondida e que tem a sua derrocada narrada como um triunfo daquele que defende a bandeira da conversăo a qualquer custo, mesmo que isso signifique o sufocamento e passamento do oponente, é aquele que reconstrói dizeres dos tempos das cruzadas, em que se carregava uma bandeira como símbolo cristăo e aqueles sujeitos avançavam impiedosamente para uma conversâo ou até mesmo para uma libertaçăo dos sujeitos pagáos da vida sem Deus.

Na sequência, os versos dizem, "segredo virou bagunça espalhado pelo châo/ depois correu atoado se jogou na maré/ banzeiro te enganou na passagem do garapé", notamos que há uma memória de destruiçăo dos locais sagrados, em que ocorrem os ritos das religiōes de matriz africana. Ao enunciar que o "segredo virou bagunça espalhado pelo chăo", os sentidos săo da destruiçâo do sagrado que é sufocado pelo poder do conquistador. Aquele que pouco se importa com as culturas dos locais onde dizem ter descoberto. Na sequência, em "depois correu atoado se jogou na maré/ banzeiro te enganou na passagem do garapé", há a retomada dos sentidos de fuga dos povos oprimidos, muitas vezes, tendo suas vidas mantidas por terem escapado por via marítima ou pelo rio, ou tendo suas vidas ceifadas, náo pela espada santa, mas pela força da natureza no desespero da luta pela sobrevivência.

A partir dessas duas toadas, notamos que existe funcionando, no Bumba meu boi, tipologias discursivas que, assim como as FDs, alternam-se na dominância do sentido e das formas tipológicas do discurso. Năo existe, em nosso corpus, um funcionamento dito puro do discurso do tipo lúdico, polêmico ou autoritário, todos se revezem, demonstrando a maleabilidade das fronteiras discursivas tanto na questăo do domínio da matriz de sentido por uma FD dominante, como no quesito da tipologia do discurso. Temos, nas toadas, um efeito de funcionamento claro do discurso lúdico por acharmos que, no Bumba meu boi, existe festa, mas também notamos que há um complexo de memórias que remontam ao período colonial e à Idade Média, demonstrando todo um discurso autoritário da demonizaçăo das culturas conquistadas, da conversăo à força e a expropriaçăo de todos os bens culturais daqueles sujeitos. E, por fim, o discurso polêmico funciona pela forma jocosa como isso é apresentado no Bumba meu boi, como forma de provocaçăo a membros de um outro grupo de Boi.

\section{CONSIDERAÇÕES FINAIS}

Ao fim das nossas análises, retomamos às nossas perguntas, săo elas: como se materializa o discurso religioso na produçâo do Bumba meu boi do Maranhâo no sotaque de matraca? Que efeitos de sentido sâo produzidos a partir da relaçâo Bumba meu 
boi/discurso religioso nas toadas do Bumba-boi que compóem o corpus da pesquisa? Essas perguntas discursivas orientaram nosso gesto analítico dando-nos um norteamento com relação a que caminhos deveríamos trilhar e como melhor trabalhar o nosso objetivo da pesquisa.

A partir dessa relaçăo pergunta discursiva/objetivo de pesquisa, conseguimos, năo esgotar as possibilidades de análise no corpus, mas apresentar alguns efeitos de sentido tendo como foco as duas toadas do Boi de Maracaná do Sotaque de Matraca. Entre nossos achados, percebemos que năo há, mesmo com o funcionamento do discurso lúdico da festa do Bumba meu boi, a ausência do discurso religioso. Esse discurso religioso é o responsável pela retomada de alguns discursos dos tempos coloniais e da Idade Média.

Resquícios do auto original, que desembarcou em terras brasileiras, por meio das caravelas portuguesas, demonstra que a essência do auto vicentino e a narrativa religiosa movimentam memórias, sentidos e sujeitos. É essa relaçăo de nós, que se ligam e, por muitas vezes, năo apresentam um começo e um fim, que trazemos o Bumba meu boi para a discussáo, abrindo a possibilidade de aprofundamento de análises para um próximo, que detalhe, ainda mais, os traços tipológicos do discurso religioso no Bumba meu boi e suas reverberaçôes em outras formas de produçăo do Boi em sua produçáo no Maranhăo. 


\section{REFERÊNCIAS}

BRANDĀO, Helena H. Nagamine. Subjetividade, argumentaçáo, polifonia: a propaganda da Petrobrás. Săo Paulo: Fundaçáo editora da Unesp: Imprensa Oficial do Estado,1998. MOISÉS, Massaud. Dicionário de termos literários. Editora Cultrix, 1985.

MONTFORT, Săo Luis Maria Grignion de. 0 segredo de Maria: Sobre a escravidăo da Santa Virgem. 1. Ed. Săo Paulo: Editora Vozes, 2018.

INDURSKY, Freda. A memória na cena do discurso. In: INDURSKY, Freda; MITTIMANN, Solange; FERREIRA. Maria Cristina Leandro. (Org.). Memória e História na/da análise de discurso. Campinas, SP: Mercado das Letras, 2011.

INDURSKY, Freda. Formaçâo discursiva: ela ainda merece que lutemos por ela por ela. Anais do SEAD. Disponível em: http://www. ufrgs. br/analisedodiscurso/anaisdosead/2SEAD/SIMPOSIOS/FredaIndursky. pdf, 2016.

ORLANDI, Eni Puccinelli. Análise do discurso: princípios e procedimentos. 12.ed., Campinas: Pontes, 2015. $\overline{1987 .}$

A linguagem e seu funcionamento: as formas do discurso. 2.ed. Săo Paulo: Pontes, PÊCHEUX, Michel. Papel da memória In: Papel da memória. Pierre Achard et al. Campinas, SP: Pontes, 1999.

PÊCHEUX, Michel. Semântica e discurso: uma crítica à afirmaçāo do óbvio. Traduçâo Eni Puccineli Orlandi [et al.]. 5.ed. Campinas: UNICAMP, 2014.

\section{REFERÊNCIAS FONOGRÁFICAS}

CHAGAS. Bumba boi da Maioba - Maioba náo para. Sâo Luís: 2013.

CHAGAS. Bumba boi da Maioba - Maioba e Lencois! Amor à primeira vista. Săo Luís: 2013. 